\title{
Application of Balanced Scorecard as a Strategic Tool, Change Management and Performance of Commercial Banks Listed in the Nairobi Securities Exchange in Kenya
}

\author{
Dr. James M .Gathungu, PhD, CPS (K) \\ Senior Lecturer-Strategy and Entrepreneurship \\ School of Business, University of Nairobi \\ Janiffer N. Nyang'au MBA \\ School of Business, University of Nairobi
}

\begin{abstract}
This study was motivated by the need to establish what effects the balanced scorecard have on change management and performance of Commercial Banks in Kenya. The study utilized a descriptive cross-sectional survey so as to determine the use of balanced scorecard as a strategic tool and its impact on management of change and performance of commercial banks. The conceptualization of this study was anchored on open system theory and supported by organization change models which include Lewin's force field analysis and Kotter's eight stage model. The target population of the research was eleven commercial banks listed in the Nairobi Securities exchange. The data used for the study was primary data. The respondents included operations managers and representatives from the top management of the banks. Data analysis was done by use of descriptive statistics as well as inferential statistics. The investigation found that the balanced scorecard assumed a major part in overseeing and monitoring change which thus means better execution. The study recommends that every commercial bank ought to constantly emphasize application of the balanced score with a specific end goal to track performance and measure it against the preset objectives. The findings of the study will serve to improve the Theory of the Balance Scorecard as a tool for performance measurement by laying out critical insights on the fundamental principles that were assessed on.
\end{abstract}

Keywords: Strategic Tool, Change Management, Balance Scorecard, Performance Measurement

\subsection{Introduction}

The development of innovation and turbulent business conditions has pushed organizations to roll out extensive modifications and improvements thus rethink methods for measuring and enhancing their performance on the key capabilities that make them competitive .Organizational change has been alluded to as the adoption of ideas, technique, procedures, or character that is new to an organization (Pierce and Delbecq, 1997). Morgan (1988) posits that expanding uncertainty would require the organization to adopt more proactive and entrepreneurial approach. Change generally is propelled by what is going on in an organization's domain, an emergent issue or unexpected events, for example, setback in expected execution, surprising moves by contenders, moves in innovation, or new client request triggers new developments (March and Simon, 1958; Levitt and March, 1988). The Balanced Scorecard was developed as a performance measurement device initially presented by Kaplan and Norton (1992), as an instrument for actualizing strategies (Kaplan and Norton, 1996). It has been embraced as a system for deciding the alignment of organization's assets and capabilities with its strategy (Kaplan and Norton, 2004).

The study was anchored on open system theory and supported by change management models. Open System theory alludes to the idea that organizations are highly influenced by their environment (Burnes, 2009). The environment consists of distinctive forces of economic, technological, political, and social nature. Since performance of firms is reliant on the fit amongst firms and their environment. The condition of firms will influence the occurrence of strategic change (Dent and Barry, 2004). 
Theoretical change management models have turned out to be instrumental in illustrating to and portraying a theoretical understanding of the change process through a number of stages. These include Lewin's Force Field Analysis and Kotter's Eight Step Model for Change. Banks in Kenya are continuously changing so that they can be able to adopt and remain competitive in the ever changing business environment. Kotter (2005) posits that in change management, a detailed plan and responsive execution is achieved through monitoring of current and future performance in all areas of the organization.

\subsection{Change Management}

Change management practices are affected by the key objectives of organizations and its external environment on the grounds that the performance of an organization depends on the fit between an organization and its external environment (Kotter, 2007). Managers in these firms are progressively becoming mindful that viably overseeing change requires the firm to have an upper hand which in turn boosts the organization's performance (Kotter, 2007).

The objective of managing change is that of anticipating unpredictable events and looking for better approaches for enhancing circumstances. Change happens beginning from the consistent activities of the organizations' individuals, as they step by step address issues and opportunities. Change is provoked from the external surrounding, pioneers make the vision of change, and the employees apply the implementation.

\subsection{Balanced Scorecard}

The balanced scorecard is a tool for strategic planning and management which is often employed at length in organizations globally in order to link business operations to the vision, mission and goals of the organization. It is a strategy and performance management instrument that plots a firm's strategic goals into performance yardsticks in four dimensions namely: Financial, customer, internal business processes, and learning and development perspectives.(Kaplan \& Norton, 1996).

The balanced scorecard includes key non-monetary performance measures to conventional monetary aspects when determining the performance measurement framework of an organization therefore giving executives a more balanced and all round perspective of the firm's performance (Kaplan \&Norton, 2006). Abdullah and Hamzah (2006) argue that the balanced scorecard approach primarily serves to transform an abstract strategy into operational action by the use of a rational set of performance metrics and the potential benefits are that it yields a balanced arrangement of performance indicators, both monetary related and non-monetary pointers covering the sum of an organization's main goal and objectives, instead of simply projecting the customary financial indicators (Atkinson, 2006).

The balanced scorecard holds monetary related measurements as a definitive measure of organizational performance. It is vital because it enables top management to decide if the mission of the organization is being supported by strategy and how it is being executed (Madsen and Stenheim, 2014). The balanced scorecard also measures client perspective of the organization since they are the main reason as to why the firm exist. How they view the firm determines whether there will be increased sales and or not (Casey and Peck, 2004). Time, quality, performance, and cost as viewed by the client is measured by the customer metrics (Kaplan and Norton, 1992).

\subsection{Strategic Management Tools and Techniques}

Strategic management is conceptualized as a collection of theories and frameworks which are reinforced by techniques as well as tools. It is intended to support top management in strategic thinking process, planning as well as strategic implementation (Stonehouse and Pemberton, 2002). Any method, model, technique, tool, technology, framework or approach that is used to facilitate strategy work is referred to as a strategic tool (Stenfors et al., 2007). A variety of strategic tools and techniques have been developed to support decision making within strategic management (Clarke, 1994; Clark and Scott 1997). To be able to improve the outcomes of various organizational functions, managers seek the help of different strategic management techniques and tools.

\subsection{Organizational Performance}

Organizational performance is a multi faceted and complex phenomenon that includes interaction of profitable resources, including employees, structural, and financial assets, where the end goal is accomplishing a common objective (Jensen and Meckling, 1976; Simon, 1976; Alchian and Demsetz, 1972; Barney, 2001). 
Stakeholders provide the required resources to the organization with the condition they are happy with returns they get, in respect to substitute commitments of these assets. Organizational performance can be judged by various demographics resulting to different translations of successful performance. Each of these viewpoints of organizational performance can be argued to be extraordinary. Further, every organization has a range of conditions, resulting to performance measurement being naturally situational (Cameron and Whetton, 1983). In view of this reality, coming up with a performance measurement model by pointing out a marker, or a set of pointers, which mirror a weighted measure of all the dimensions of performance in the form of return created is fundamental. An acceptable measure should consider data on both chronicled performance and also desired future performance.

\subsection{Literature Review}

Several theories have been developed by different scholars that touch on change and performance. Among them include the open systems theory where the organization is presented as an open system which is largely affected by its environment. Change a management model which covers the different stages in change management implementation.

\subsection{Open System Theory}

The open systems view of management considers organizations to be open systems. The theory suggests that organizations are largely influenced by their environment (Bastedo, 2006). An open system communicates with the surrounding environment in terms of inputs and outputs. This interaction with the surroundings infers that open systems should have the capacity to adapt to the changes that happen in their surroundings. Organizations being open systems are made out of various interconnected sub- systems. These include hierarchical objectives and values sub-systems, the psychological sub-system, the technical sub-system and the administrative subsystem. The open systems approach structures the elements of a business such that through characterized lines of coordination, the general business goals are all sought after (Burnes, 2009).

This theory posits that organizations whose internal features best match the demands of their environmental situations will achieve the best adaptation (Mullins 1989). Any action a manager may take is contingent on the prevailing environmental conditions (Buckley 1968). Despite the support open system theory has received from eminent researchers such as Burns and Stacker (1961) woodward (1965). Lawrence and Lorsch (1967) Kanter (1989) and Senge (1990). Criticisms have equally been levelled against the theory. For example, Beach (1980) and Butler (1985) have contended that the theory does not comprise a consistent, articulated coherent theory and much of it constitutes abstraction.

\subsection{Organizational Change Models}

Amongst the most common subjects of management theory and practice, organizational change has risen in the course of recent decades as a standout (Pettigrew et al., 2001; Sturdy and Gray, 2003,Doolin, 2003;). Pierce and Delbecq, (1997) posits that organizational change is the selection of thoughts, procedures, methodology or conduct that is new to the organization. A firm transitions from the current state towards a coveted future state with the end goal, which is to enhance proficiency and sustainable existence (Cummings and Worley, 2005). Bumes, (2009) presents change as a multi-level process which is cross-organizational and which divulges a composed as well as skilled pattern across a timeframe which involves a progression of intertwining systems.

Change is also characterized as a monitored system, process and/or behavioral reaction over time to trigger occasion (Struckman and Yammarino, 2003). They consider change as a procedure rather than an activity. Berger (1994) characterized management of change as a continuous process of aligning an organization to its marketplace and doing it more responsively and successfully than competitors. The need for change in the organization has been highlighted by Clarke (1994). He explains further that this change is needed in order to manage ecological weights and to accomplish the goals of persistent survival and development.

Meyer (1982), contends that in order to adapt to unexpected shifts in the organizational environment, change is paramount. The adoption of change by a firm has been characterized as a test to the operational routine in an organization (Vakola and Nikolaou, 2005). This often brings about sentiments of instability from people due to the uncertainties about the probable disappointment of delivering according to the new standards. Likewise, it is characterized as an intentionally engineered reaction to shifts in the surroundings (Jimmieson et al., 2004). 
Change management is a remotely determined flow of actions which focuses on the organizations reaction to external developments as well as how they adjust in order to build authenticity and strong foundations (DiMaggio and Powell, 1983; Aldrich, 1999).The main focus of models of change is typically to distinguish the purpose behind the change, thus creating an all-round sensitivity to criticalness as well as indicating and imparting the intended goal to be reached (Cummings and Worley, 2005, Kotter, 1995).

\subsection{Lewin's Force Field Analysis}

Kurt Lewin was among the first scholars to craft a change model in 1947. The Lewin's model is broken down into three stages: unfreeze, change and refreeze (Lewin, 1947). These stages describe a process where a firm transitions beginning with one harmony point to another. The model offers a basis for the comprehension of organizational change and advancement.

The unfreezing stage alludes to changing the current state which is characterized by present practices and mentalities in the organization (Armstrong, 2006). This process entails intensive analysis of threats that might result due to change and then inspires the individuals affected to achieve a state of balance brought by tolerating change (Armstrong, 2006). An essential prerequisite in this stage is the need for organizations to self-reflect and work on the ways of inclusion so as to inspire and prepare top performers in the organization to surrender the profoundly established routines (Schreyogg and Noss, 2000).

The second step referred to as changing, alludes to psychological setting, where the individuals get information as well as reliable proof demonstrating that change is alluring as well as conceivable (Schreyogg and. Noss, 2000). This stage is the point at which the change really happens. Individuals take in the new plans, practices, frameworks, structures, procedures and policies. The final step referred to as refreezing sets perpetuity all adjustments made in the second step and a new harmony instilled in the organization (Cummings and Worley. 2005). The events comprise process set up which guarantees the new conduct measures and securing against relapse to earlier methods of conduct. The practices that have been recently learned are installed by continuous repetition in an instructional session and demonstrations to illustrate how to employ the new skill in real work circumstance (Iles \&Sutherland, 2001).

\subsection{Kotter's eight Step Model of Change}

The eight step model for change was developed by Kotter,(1995), a leadership and change management expert. His goal was to battle what he regarded were primary purposes behind unsuccessful change process in organizations (Kreitner\&Kinicki, 2007). He concentrates driving on change as opposed to overseeing it. Kotter, $(1995,1996)$ built up the model for use at the strategic level of a firm to guide them in the change of vision then consequently change entire firm. Kotter (1996) suggested eight steps to aid the management of change. They outlined the progression of change administration stages where sense of urgency is created followed by a team of top managers forming a guiding coalition while continuously creating urgency and momentum revolving around the reasons why change is important. Vision and strategies formulation which will aid the achievement of change goals enables focused expedition. Relaying the vision in comprehensible channels to involved parties is the fourth step.

The fifth step is to deal with obstructions and evaluation so as to be able to engage the rest of the team to follow up on the objectives of implementing the new vision. It is important for managers to create short wins. Managers should encourage imaginative critical thinking to introduce more change and finally, it is important to anchor new approaches in organizational culture. Kotter's eight stage models provide a detailed guidance for implementing changes in behaviours, frameworks and structures in organizations.

As indicated by Burnes (2009), the stages were encouraged to be viewed as a procedure and not as a checklist. Moreover, Kotter (1996) asserted that major change endeavors was mainly as a result of little and medium-sized change venture holding the view that firms that the new ways of doing things was a consequence resulting from the assumption that 'change is a constant, liberal as well as eccentric process of adjusting and matching an organization to its evolving surrounding. Subsequently, managing change using this model has turned out to be most preferred within firms in the contemporary world due to the fact that it points out the importance of organizations adjusting their strengths and weaknesses to match the challenges and opportunities that are present in the external surrounding (Burnes 2009). 


\subsection{Balanced Scorecard and Change Management}

When organizations are conceptualizing management of change and how performance will be affected, it is important to consider the process of implementation. The deliberate method of managing change is firmly related to recognizing and handling procedures intended to make organizations more prosperous and competitive. These progressions are within the firm as well as externally engrossed. Planning sets directions that are clear, assesses resources and also sets course with goals and objectives that are clear (Graetz et al., 2002). As indicated by Becker (2011) building up a performance measurement framework that is worlds class is anchored on reasonable comprehension of the operational objectives for the firm, as well as an authoritative explanation of employees capabilities and practices necessary to accomplish goals set by the firm.

Value can only be created by measurement frame works when they are matched carefully with the strategy and objectives of the firm. It is also important for the information presented for measurement to be verifiable, exact, accessible as well as complete. Conveying agreeable results over all measures as opposed to one zone is the indicator of effective performance. (Armstrong and Baron, 1998). The balanced scorecard is a key instrument utilized by organizations to streamline firm operations and match them to the strategy by measuring actual against preset performance objectives. Being a planning and process improvement framework, the primary focus of the balanced scorecard is on driving performance of a firm by recognizing correlated aspects of performance and assessing their performance. Chan (2004) points out the critical role that the framework plays during a firm's mission identification, procedure definition and process execution.

Firms concentrate on four execution metrics when they are gauging performance using the balanced scorecard. These metrics include learning and growth, customer, internal process, and financial measures (Kaplan and Norton, 2002). The balanced scorecard measures these four metrics in order to enable tracking of all the vital parts in a company's system and in addition accomplish continuous change of the organization.

\subsection{Balance Scorecard and Organizational Performance}

Performance and its measurement in organizations has been a subject for researchers as well as experts since the earliest formation of organizations. At the heart of several disciplines is the concept of organizational performance and whether resources are being utilized effectively so as to accomplish coveted results. Ideally, organizational performance includes the real yield of a firm as compared to set targets and goals. While trying to overcome any issues amongst theory and practice, Kaplan and Norton (2005) suggested that viable organizational performance ought to be measured utilizing a balanced scorecard.

Initially presented as a performance measurement tool by Kaplan and Norton (1992), the balanced scorecard has evolved to a tool of actualizing procedures and a structure for determining the organization of human, data and organization's capital with its strategy. Kaplan and Norton (1996) posit that since good financial performance was as a result of basic operational measures, it was important to also focus on measuring non-financial aspects so as to get a general viable organizational performance.

The component of balanced scorecard makes it to portray a multi-disciplinary perspective of the performance of a firm. The comprehension of the set goals and objectives of the firm as well as procedures employed to quantify their achievement is key when determining performance management (Hofer and Schendel 1978).

\subsection{Balanced Scorecard, Change Management and Performance}

Many studies have been conducted to scrutinize how utilizing the balanced score card affects performance. These have mainly concentrated on the two rudimentary scopes which are: the degree of use and the method of use. Findings from studies on the levels of use (Hoque\& James, 2004; Ittner, Larcker\& Randall, 2003; Davis \& Albright, 2014) have indicated that there are both positive as well as negative relationships between balanced scorecard utilization and performance.

The findings on studies conducted on the manner of balanced scorecard use (Lipe \& Salterio, 2002; Olson \& Slater, 2002; Malina \& Selto, 2001) confirm the fact that there exist serious differences in the ways in which organizations implement and use the balanced scorecard. The balanced scorecard has an effect on the information value it provides necessary for making decisions. When co-aligned wisely to the corporate strategy, it aids a firm's strategic effort and grows performance. The outcomes advocate that the intensity or level of use impacts the performance of the firm but the quality or manner of balanced scorecard use is crucial (Braam \& Nijssen, 2004). 
In Kenya, studies have been done on the how the use of the balanced scorecard affects performance. Thuo (2012) researched the difficulties in the usage of the balanced scorecard device at Safaricom Kenya Limited. She discovered that the greatest challenge was the multifaceted nature of the tool and its remedy of measures that couldn't reverberate with the reality of the Kenyan market.

Ombuna, Omido, Garashi, Odera and Okaka (2012) in their study on how the usage of the balanced scorecard impacted on their performance of commercial banks found a positive impact of balanced scorecard usage on performance of commercial banks. It was noted by a majority of the respondents that considerable achievements had been realized through the use of the balanced scorecard. Nyaega (2012) in his study titled application of balanced scorecard in performance measurement at Essar telecom Kenya Limited, found out that Essar telecom used the balanced scorecard primarily for strategy implementation and performance measurement but due to challenges have been unable to harness the full benefits of the tool.

Table 2.1: Summary of empirical studies and knowledge gaps

\begin{tabular}{|c|c|c|c|}
\hline Study & Methodology & Main Findings & Knowledge Gaps \\
\hline $\begin{array}{l}\text { Impact of the balanced scorecard } \\
\text { usage on performance of } \\
\text { commercial banks. } \\
\text { Ombuna, et al., (2012) }\end{array}$ & Descriptive survey & $\begin{array}{l}\text { There is a positive impact } \\
\text { in usage of balance } \\
\text { scorecard }\end{array}$ & $\begin{array}{l}\text { The study concentrated on the } \\
\text { internal environment and did not } \\
\text { consider the influences of the } \\
\text { external environment }\end{array}$ \\
\hline $\begin{array}{l}\text { Application of balanced scorecard } \\
\text { in performance measurement at } \\
\text { Essar telecom Kenya Limited. } \\
\text { Nyaega (2012) }\end{array}$ & Case study & $\begin{array}{l}\text { The benefits of the } \\
\text { balanced scorecard } \\
\text { outweigh the costs }\end{array}$ & $\begin{array}{l}\text { The study was limited to a } \\
\text { specific organization, therefore } \\
\text { compromising external validity } \\
\text { of the findings. }\end{array}$ \\
\hline $\begin{array}{l}\text { Differences in balanced scorecard } \\
\text { implementation methods. } \\
\text { Lipe \& Salterio, (2002) }\end{array}$ & $\begin{array}{l}\text { Cross sectional } \\
\text { survey }\end{array}$ & $\begin{array}{l}\text { There are serious } \\
\text { differences in balanced } \\
\text { scorecard implementation } \\
\text { methods and usage }\end{array}$ & $\begin{array}{l}\text { The study did not consider } \\
\text { variations in external } \\
\text { environment that may influence } \\
\text { the performance outcome }\end{array}$ \\
\hline $\begin{array}{l}\text { Relationship between balanced } \\
\text { scorecard application and } \\
\text { performance outcome in } \\
\text { Multinational Corporations listed } \\
\text { in the NSE. } \\
\text { Kimaro, }(2013) \\
\end{array}$ & $\begin{array}{l}\text { Cross sectional } \\
\text { survey }\end{array}$ & $\begin{array}{l}\text { There is a positive } \\
\text { relationship between } \\
\text { application of balance } \\
\text { scorecard and performance }\end{array}$ & $\begin{array}{l}\text { The study focused on } \\
\text { multinational corporations listed } \\
\text { in the NSE but did not consider } \\
\text { the aspect o change and how it } \\
\text { can affect measurement and } \\
\text { performance }\end{array}$ \\
\hline $\begin{array}{l}\text { Reasons why organizations need } \\
\text { a performance measurement } \\
\text { system. } \\
\text { Averson, (1998) }\end{array}$ & $\begin{array}{l}\text { Cross sectional } \\
\text { survey }\end{array}$ & $\begin{array}{l}\text { Scorecard enables the } \\
\text { identification of the best } \\
\text { practices in an organization } \\
\text { and expand their usage } \\
\text { elsewhere }\end{array}$ & $\begin{array}{l}\text { The study focused on the } \\
\text { importance of using a balanced } \\
\text { scorecard as a measurement tool } \\
\text { but did not cover the different } \\
\text { situational aspects of } \\
\text { organizational performance } \\
\text { measurement }\end{array}$ \\
\hline
\end{tabular}

\subsection{Methods}

The study adopted a descriptive survey design.

The target population was all the listed commercial banks in Kenya. Primary and secondary data was employed in this study. Primary data was gathered by use of self-administered questionnaires. The interview method of collecting data was applied when collecting data from top level managers. Analysis of the data collected was done using descriptive statistics. Multiple regressions were also used to measure the association between the dependent and independent variables. 


\subsection{Results and Discussion}

Table 4.1: The value and use of performance measures

\begin{tabular}{|l|l|l|l|}
\hline \multicolumn{4}{|l|}{} \\
\hline ITEMS & $\mathrm{N}$ & Mean & $\begin{array}{l}\text { Std. } \\
\text { Deviation }\end{array}$ \\
\hline $\begin{array}{l}\text { - Measures are clearly defined in each performance } \\
\text { area }\end{array}$ & 16 & 3.6875 & .47871 \\
\hline $\begin{array}{l}\text { Measures are used for management and decision } \\
\text { making }\end{array}$ & 16 & 3.5000 & .51640 \\
\hline - Measures are used for regular management reviews & 16 & 2.3750 & .50000 \\
\hline - Measures are used for strategic planning & 16 & 3.6875 & .47871 \\
\hline - Measures are used to drive change & 16 & 3.7500 & .44721 \\
\hline & & & \\
\hline
\end{tabular}

The table 4.1 shows that majority of the respondents agreed that the balanced scorecard measures are clearly defined in each area of performance as indicated by a mean of 3.68. They also indicated that the balanced scorecard measures facilitate driving change as well as a basis for strategic decision making for management as indicated by means of 3.75, 3.68 and 3.50 respectively. Most respondents however indicated that management reviews using the balanced scorecard measures were not very common as indicated by a mean of 2.3.These results imply that the commercial banks make use of the balanced scorecard in driving and managing change, as well as monitoring performance.

Table 4.2. Role of the balanced scorecard

\begin{tabular}{|l|c|c|l|}
\hline ITEMS & $\mathrm{N}$ & Mean & $\begin{array}{l}\text { Std. } \\
\text { Deviation }\end{array}$ \\
\hline - Balanced scorecard communicates areas of weaknesses and strengths & 16 & 4.4375 & .51235 \\
\hline - Balanced scorecard allows managers identify best practices in an organization & 16 & 4.6250 & .50000 \\
\hline - Balanced scorecard is objective and consistent & 16 & 4.4375 & .51235 \\
\hline - Balanced scorecard establishes sufficient ownership and accountability & 16 & 4.6875 & .47871 \\
\hline - Balanced scorecard has led to improved performance of the organization & 16 & 4.4375 & .51235 \\
\hline - $\begin{array}{l}\text { Balanced scorecard measures chosen are relevant to the organization's strategy and } \\
\text { vision. }\end{array}$ & 16 & 4.3750 & .50000 \\
\hline
\end{tabular}

Table 4.2 presents the role balanced scorecard played on performance, monitoring and measurement. The means of $4.43,4.46,4.43,4.68,4.43$ and 4.37 respectively strongly indicate that the majority of the respondents agreed that the balanced scorecard played a very big role in performance, management and measurement.

\subsection{Regression Analysis}

A regression analysis was carried out to find out the relationship that exists between the balanced scorecard and management of change as well as performance of NSE listed commercial banks in Kenya. The regression equation adopted is $Y=\beta 0+\beta 1 \times 1+\beta 2 \times 2+\beta 3 \times 3+\beta 4 \times 4+\varepsilon$; where $Y=$ Performance/ change management, $\beta 0=$ the constant of regression, $\beta 1, \beta 2, \beta 3$ and $\beta 4=$ are the regression coefficients/weights of the following respective independent variables; $\mathrm{x} 1=$ Financial perspective, $\mathrm{x} 2=$ Customer perspective, $\mathrm{x} 3=$ Business processes perspective, $\mathrm{x} 4=$ Learning and growth perspective and $\varepsilon=$ error term.

\begin{tabular}{|l|l|l|l|l|}
\hline \multicolumn{5}{|c|}{ Table 4.3: Model Summary } \\
\hline Model & $\mathrm{R}$ & R Square & Adjusted R Square & $\begin{array}{l}\text { Std. Error of the } \\
\text { Estimate }\end{array}$ \\
\hline 1 & $.712^{\mathrm{a}}$ & .680 & .750 & .03126 \\
\hline a. Predictors: (Constant), Balanced Scorecard. \\
\hline
\end{tabular}


The independent variable that was studied was the balanced score card. $68.0 \%$ variation of performance is therefore significantly explained by the variation in the independent variable. It is established by the regression equation that when the independent variable is held constant, other factors influencing change and performance will be $32.0 \%$.

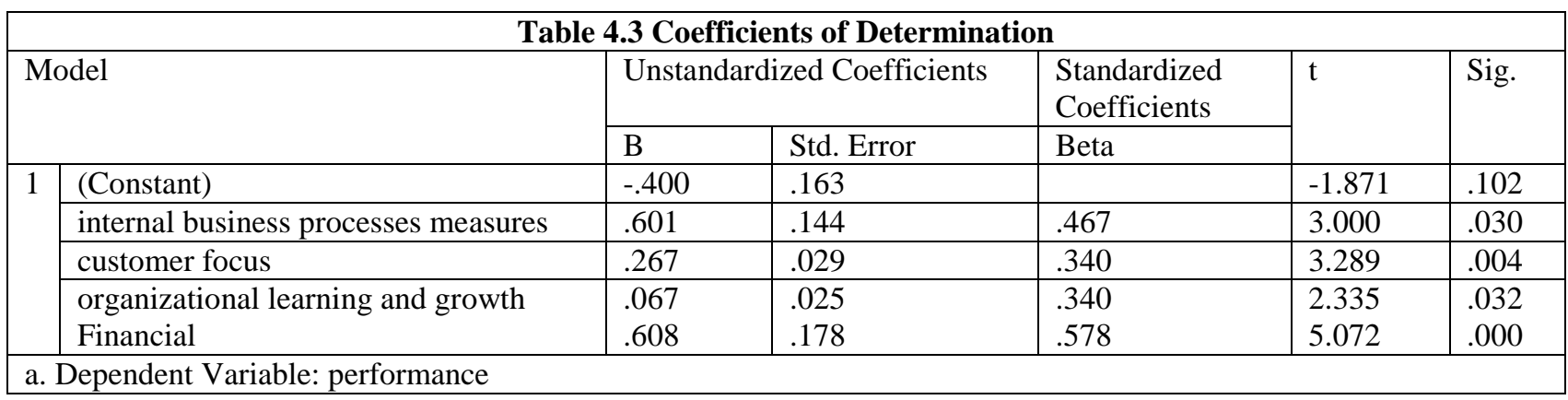

The study established that there is significant relationship between the balanced scorecard, management of change and performance of listed commercial banks; Financial perspective $(\mathrm{p}=0.000<0.05)$, Customer perspective $(p=0.004<0.05)$, Business processes perspective $(p=0.003<0.05)$ and Learning and growth perspective $(p=0.032<0.05)$. The testing of the coefficients of regression for significance was done at alfa $=0.05$. Significance occurs when $p$-values is less than 0.05 . According to the results, all variables are good predictors for performance in these commercial banks. These findings were in line with that of Asaasira (2016) whose findings illustrated that the adoption of the balanced scorecard in tier one commercial banks in Kenya has been highly effective overtime.

\subsection{Discussion of Results}

This study presents an analysis of the influence of the balanced scorecard use on change management and performance of commercial banks listed in the NSE. The results of the study showed that the information from the balanced scorecard helped managers in making informed decisions which lead to improved operational and financial performance of the company. All the managers agreed that the objective being measured must be aligned to the strategy and vision of the company in order for it to perform and succeed. The balanced scorecard through its strategic mapping has been able to create a cause and effect relationship of the four perspectives being measured which in the long run leads improved performance of the institutions.

In some of these commercial banks, the balanced scorecard was merged with the Management by Objectives (MBO) tool while the majority, of the banks the instrument was largely used under varying labels with the same underlying concept of managing employees' performance along the strategy implementation process. According to Kaplan and Norton (2006), a balanced scorecard helps in the performance management process by clearly classifying the consumers and also segments in the market in which the organization may select to compete. The study revealed that majority of listed Commercial Banks had a structured way of drawing the performance measures where the process began with top management and then the objectives were cascaded down to the lower levels.

According to McKenzie and Shilling (2008), many times, the application and implementation of the balanced scorecard never actualizes because of the tool's failure to live up to the users' expectations. Even though the potential benefits from implementation of a balanced scorecard are numerous, it has been noted that majority of the balanced scorecard projects do not materialize. The study, therefore, established that accurate adoption and implementation of the balanced scorecard facilitates positive achievements in regards to change management which in the long run results to better performance.

The study established that change management at Commercial Bank has been successful since the adoption of Balanced scorecard, the tool has enabled the organization to develop the likelihood of successfully carrying out strategy, disbursement of enough resources to activities that are strategy essential, come up with strategyencouraging policies, engage best policies and programs for continuous development, connect payment structure to achievement of set targets and utilize the strategic leadership. 
The findings of this study also concur with the study findings of Mulu (2010) who found out that the balanced scorecard's learning and growth perspective facilitated and drove the organization learning and career as well as employee development process towards the attainment of organization mission (Mulu, 2010). The balanced scorecard had been used to identify gaps that existed between the planned and the actual performance; the needs that arose from these gaps were then filled through skills development as well as establishment of training and development programs.

This study is in line with Neely, (2007), who argued that for an organization to survive over a long period of time, the balanced scorecard must provide the organization a long run renewal for it to cope with the changes in the environment.

Application and balance score card faces several challenges. Balanced scorecard starts from the assumption that the linkage between different points of time must be understood. Viewed from this point, no explanation is given by the balanced scorecard on the role of time in its cause-and-effect relationships. This is in line with Norrekelit (2011), who noted that the time dimension in regards to cause and effect relationship is not incorporated in the balanced scorecard, neither does it separate cause-and effect relationships in time.

Integration issues where the top-levels and operational levels measures are not balanced is also a challenge. This results to the balanced scorecard failing to identify the measurement of performance as a two ways process. Internal focus stands out as one of the criticisms of balanced scorecard in such a way that the internal processes of an organization are encouraged by the framework.

\subsection{Conclusion}

The main objective of the study was to establish the influence balanced scorecard had on management of change as well as performance of listed commercial banks. Based on the analysis of responses, the respondents were in agreement that the adoption and utilization of the balanced scorecard has helped them in managing change and also in formulating objectives that are aligned to the organization's vision, strategy, goals and improve communication both within the firm and also externally and to set strategic goals.

The study further found that the strategy and objectives of the company are communicated through the balanced scorecard from top management to the divisional, departmental, sectional and managerial heads where each creates a scorecard linked to the strategic themes and objectives set for the financial year. This creates a synergy between the corporate strategies, business units' strategy and finally to the individual objectives of the employees in the organization. This ensures that the objectives being measured and monitored are aligned to the company's goals and strategy.

The study found out that the respondents measured performance based on the four perspectives of the balanced scorecard. The results showed that the respondents agreed on the importance of both financial and non-financial measures of performance for the company. They further agreed that by using the balanced scorecard they have been able to improve the operational and financial performance of the organization through the use of information generated from the balanced scorecard to make informed and quality decisions.

From the results, the balanced scorecard use as a strategic management and performance management system in organization has been clearly linked to the management of the organization being able to clarify the vision, mission and strategy through creating of scorecards for the several business units that have objectives aligned to the overall corporate strategy of the company. 


\section{References}

Abdullah, P. and S. M. Hamzah, (2006). Obstacles to successful implementation of Strategic decisions: The British experience, European Business Review, Vol. 98 No.6,pp.322-7.

Alchian A. and H. Demsetz, (1972). Production, Information Costs, and Economic Organization. 62 (1972) p 777. Aldrich H. (1999). Organizations Evolving. Thousand Oak, CA:Sage.

Armstrong M. (2006). Performance Management ; a strategic and integrated approach to achieve success $9^{\text {th }}$ ed Mumbai Naic Publishing House.

Armstrong M. and Baron A., (1998).Performance Management, The New Realities, London, Institute of Personnel and Development. Ansoff, I. (1965). Corporate strategy, New York,McGraw Hill.

Atkinson, H. (2006). Strategy Implementation: A Role for the Balanced Scorecard, Management Decision, Vol. 44, 1447-1448.

Averson, P. (1998). Background and History of Measurement Based Management. Balanced Scorecard Institute.

Barnes J.B. (2001) is the resource based new a useful perspective for strategic management research? yes. The Academy of Management Reviews 26 (1).

Bastedo, M.N. (2006). Open systems theory. The sage Encyclopaedia of Educational Leadership and Administration. Thousand Oaks, CA: Sage.

Beach S.D. (1980). Personnel London, MacMillian.

Becker B, M. Huseld and D. Ulrich,(2011).The HR Scorecard, Linking People Strategy, and Performance, Boston, Harvard Business School Press.

Butler V.G. (1985). Organization and Management, London Prentice- Hall.

Burckley W. (1968). Modern System and Research for the Behavioral Scientist, Chicago, Aldine Publishing.

Burnes,P.G. (2009). Managing Change: A Strategic Approach to Organizational Change,2nd Edition, London: Pitman Publishing.

Burns T. and Stalker H.M. (1961). The Management of Innovation London, Tavistock.

Cameron, K.S., \& D. A. Whetton, (1983).Organizational effectiveness: A comparison of Multiple models, New York: Academic Press, Inc. pp. 1-24, 261-277).

Casey, W. and W. Peck. (2004). Goal Alignment: Foundation for Efficient Strategy Execution Denver. Executive Leadership Group.

Chan, L. (2004). Performance measurement and adoption of the balanced scorecard: A Survey of the Municipal governments in the USA and Canada: The International Journal of Public Sector Management, Vol.17, No. 2, pp. 21.

Clarke L. (1994). The Essence of Change, London, Prentice-Hall.

Cummings, T.G. and C. G. Worley (2005).Organization Development and Change, $8^{\text {th }}$ Edition, Cincinnati, OH: South-Western College Publishing.

Davis, S., \& T. Albright (2014). An investigation of the effect of balanced scorecard Implementation on financial performance. Management accounting research,15(2), 135-153.

Dent, M. and J. Barry, (2004). New Public Management and the Professions in the UK: Reconfiguring Control.Aldershot: Ashgate, pp. 7-20.

Dimaggio P. and Powell D. (1983). The Iron Case Revisited. Institutional Isomorphism and collective Nationality in Organization fields. American Sociological Review 48, 147-160.

Doolin, B. (2003).Narratives of change: discourse, technology and organization", Organization, Vol. 10 No. 4, pp. 751-70.

Graetz, F., M. Rimmer, A. Lawrence, and A. Smith,(2002). Managing organizational change. Queensland, John Wiley \& Sons Australia Limited.

Hill.Clark, D. N. and J. L. Scott, (1997).Strategic Management Tool Usage: A Comparative Study, Strategic Change, 6(7), pp. 417-427.

Hofer, C. W., \&D. Schendel, (1978). Strategy Formulation. St. Paul, MN: West Publishing.

Hoque,S.R., (2004). A contingency model of the association between strategies, Environmental uncertainty and performance measurement: impact on Organizational performance. International Business Review, 13(4), 485-502.

Iles V. \& k. Sutherland (2001). Managing Change in NHS-Organizational Change A Review for Health Care Managers Professionals and Researchers. National Coordinating Centre for Service Delivery, London. 
Jensen, M. and W. Meckling, (1976). Theory of the firm: managerial behaviour, agency Costs and ownership structure, Journal of Financial Economics 3, 305-360.

Jimmieson N. D. Terry and V. Callan, (2004). A longitudinal study of employee Adaptation to organizational change: The role of change related information and Change related self-efficacy. Journal of occupational Health Psychology, 9, 11-27.

Kanter R.M. (1989). When Giants Learn to Dance: Mastering the Challenges of Strategy Management and Careers in 1990s London Unwin.

Kaplan, R. S. \&D. P. Norton, (1992). The balanced scorecard: Measures that drive Performance. Harvard Business Review.

Kaplan, R. S. \& D. P. Norton, (1996). The Balanced scorecard, Boston: Harvard Business School Press, 1996.

Kaplan, R. S. \& D. P. Norton, (2002). Strategy maps; Converting Intangible Assets into Tangible Outcomes. Harvard Business Review. Harvard Business School Press.

Kaplan, R. S. \& D. P. Norton, (2005). The Balanced scorecard: Measures That Drive Performance. Harvard Business Review, July 2005, pp. 71-79.

Kimaro, C. (2013). Application of Balanced Scorecard in Strategy Implementation at Deloitte \& Touche East Africa. International Journal of Advanced Research, 2 (4 ), 54-61.

Kotter, J. P. (1995). Leading change: Why Transformation Efforts Fail. Harvard Business Review, 73(2), 59-67.

Kotter, J. P., (1996). Leading Change. Boston: Harvard Business School Press.

Kotter, J. P.,(2007). Leading Change: Why Transformation Efforts Fail. Harvard Business Review. 98(2), 71-79.

Kreitner, R. \& A. Kinicki (2007). Organizational Behavior ( $7^{\text {th }}$ ed). Boston; London: McGraw Hill Orwin.

Lawrence P.R. and Lorsch J.W. (1967). Organization and Environment Boston, Harvard Business School.

Levitt, B. and J. G. March. 1988. Organizational learning. Annual Review of Sociology.14: 319-340.

Lewin K. (1947). Frontiers in group dynamics in D Castwright (1952): Field theory in Social Science. London, Social Science Paper Backs.

Lipe, M.G and S.E. Salterio (2000). The Balanced Scorecard: Judgmental Effects of Common and Unique Performance Measures. The Accounting Review. 75 (3) pp. 283-298.

Malina, M. A., \& F. H. Selto, (2004). Choice and change of measures in performance Measurement models. Management Accounting Research, 4(22), 547.

Madsen, D., \& T. Stenheim, (2014). Perceived benefits of balanced scorecard Implementation: some preliminary evidence. Problems and Perspectives in Management, 12(3), 81-90.

March, J. G. and H. A. Simon, (1958). Organizations, New York: Wiley.

Meyer, M.W. (1982), Rethinking performance measurement: beyond the balanced Score card', Cambridge: Cambridge University Press.

McKenzie, F. D., \& M. D. Schilling (2008). Avoiding performance measurement traps: Ensuring effective incentive design and implementation. Compensation and Benefits Review July-August 30 (4): 57.

Morgan G. (1988). Riding the waves of Change, San Francisco, Jossey- Bass.

Mulu, A. K. (2010). Challenges of the balanced score card in strategy implementation in Ernst \& Young, Kenya (unpublished MBA project), University of Nairobi.

Mullins L. (1989). Management and Organizational Behavior London Pitman.

Neely, A. M. (2007). Designing performance measures: a structured approach. International Journal of Operations \& Production Management, 11(17), 1131-1152.

Norreklit, H. (2011). The balance on the balanced scorecard a critical analysis of some of Its assumptions. Management accounting research, 11(1), 65-88.

Nyaega, G. (2012). Application of Balanced Scorecard in Performance Measurement at Essar Telecom Kenya Limited. Journal of Management and Business Studies, 1 (1), 29-34.

Ombuna, D.S.,K. Omido, H.M. Garashi, O.Odera \& O. Okaka (2012). Impact of Balanced Scorecard Usage on the performance of Commercial Banks. International Journal of Information Technology and Business Management, 10 (1), 40-48.

Pierce J. L., and A. L. Delbecq, (1997). Organization Structure, Individual Attitudes and Innovation, Academy of Management Review, Vol. 2, pp27-37.

Pettigrew, A.M., R. W. Woodman, \&K. S. Cameron, (2001). Studying Organizational Change and Development: hallenges for Future Research, Academy of Management Journal, vol. 44, no. 4, pp.697-713. 
Schreyogg, G \& C. Noss (2000). Reframing change in organization: The Equilibrium Logic and Beyond. Academy of Management Proceedings. ODC 2000 Best Paper Award.

Senge P.M. (1990). The fifth Discipline: The Art and Practice of the Learning Organization London Century Business.

Simon, H. A. (1976). Administrative Behavior. A Study of Decision-Making Processes in Administrative Organization, Third Edition, The Free Press, Collier Macmillan Publishers, London, UK.

Stenfors S, L. Tanner, M. Syrjanen, T. Seppala, and I.Haapalinna,(2007). Executive Views concerning decision support tools. 181(2): pp. 929-938.

Stonehouse, G. \&J. Pemberton, (2002). Strategic Planning in SMEs - Some Empirical Findings', Management Decision, 40 (9), 853-861.

Struckman, C. H. and F. J. Yammarino, (2003). Organizational Change and Development, JAI Press, Greenwich, Vol. 14 (2003).

Sturdy, A. and C. Gray, (2003). Beneath and Beyond Organizational Change Management, Organization, Vol. 10 No. 4, pp. 651-62.

Thuo, E.W. (2012). The Challenges of Implementation of the Balanced Scorecard Strategy at Safaricom Kenya Limited. (Unpublished MBA Project). University of Nairobi.

Woodward J. (1965). Industrial Organizations; Theory and Practice London, Oxford University Press.

Wright,R.P.,S.ParoutisandD.P.Blettner, (2013). How useful are the strategic tools We teach in business schools? Journal of Management Studies, 50, pp. 92-125.

Vakola, M., I. Nikolaou, (2005). Attitudes towards organizational change, 27(2): 160-174. 